\title{
Recent progress on deep eutectic solvents in biocatalysis
}

\author{
Pei Xu ${ }^{1,2}$, Gao-Wei Zheng ${ }^{3}$, Min-Hua Zong ${ }^{1,2}$, Ning Li ${ }^{1}$ and Wen-Yong Lou ${ }^{1,2^{*}}$ (D)
}

\begin{abstract}
Deep eutectic solvents (DESs) are eutectic mixtures of salts and hydrogen bond donors with melting points low enough to be used as solvents. DESs have proved to be a good alternative to traditional organic solvents and ionic liquids (ILs) in many biocatalytic processes. Apart from the benign characteristics similar to those of ILs (e.g., low volatility, low inflammability and low melting point), DESs have their unique merits of easy preparation and low cost owing to their renewable and available raw materials. To better apply such solvents in green and sustainable chemistry, this review firstly describes some basic properties, mainly the toxicity and biodegradability of DESs. Secondly, it presents several valuable applications of DES as solvent/co-solvent in biocatalytic reactions, such as lipase-catalyzed transesterification and ester hydrolysis reactions. The roles, serving as extractive reagent for an enzymatic product and pretreatment solvent of enzymatic biomass hydrolysis, are also discussed. Further understanding how DESs affect biocatalytic reaction will facilitate the design of novel solvents and contribute to the discovery of new reactions in these solvents.
\end{abstract}

Keywords: Deep eutectic solvents, Biocatalysis, Catalysts, Biodegradability, Influence

\section{Introduction}

Biocatalysis, defined as reactions catalyzed by biocatalysts such as isolated enzymes and whole cells, has experienced significant progress in the fields of either biocatalysts or reaction medium during the past decades. One noteworthy example is the greener synthetic pathway developed by Savile for the redesigned synthesis of sitagliptin, an active ingredient used to treat diabetes (Savile et al. 2010). Generally, biocatalysis refrains many weaknesses, such as the lack of enantio-, chemoand regioselectivity and utilization of metal catalysts in organic synthesis in the production of valuable compounds by the chemical method (Bommarius and Paye 2013).

Along with the rapid emergence of new biocatalyst technology, the shift to green chemistry puts high stress on the biocatalytic process. Among the Twelve Principles of Green Chemistry developed by Anastas and Warner

\footnotetext{
*Correspondence: wylou@scut.edu.cn

${ }^{1}$ Laboratory of Applied Biocatalysis, School of Food Sciences and Engineering, South China University of Technology, Guangzhou 510640, China

Full list of author information is available at the end of the article
}

(1998), one concept is "Safer Solvents and Auxiliaries". Solvents represent a permanent challenge for green and sustainable chemistry due to their vast majority of mass used in catalytic processes (Anastas and Eghbali 2010). Environmental benignity is the ideal pursuit of exploiting each generation of solvents.

Solvents for a biocatalysis reaction have experienced several generations of development. Water has been considered as the greenest solvent considering its quality and quantity. However, the high polarity of the water molecule hinders its application in all biocatalytic reactions, because of some substrates' insolubility in aqueous solution due to their high hydrophobicity. Traditional organic solvents (water miscible or water immiscible), in the form of co-solvents or second phase, can provide solutions for the above-described challenges to some degree. But inevitably, organic solvents face their own disadvantages such as high volatility, inflammability and activity inhibition to the biocatalyst. Ionic liquids (ILs) are the first enzyme-compatible untraditional media developed by the green and sustainable concept (given their low vapor pressure). Numerous reactions, e.g., hydrolytic and redox reactions as well as formation of $\mathrm{C}-\mathrm{C}$ bond, have been successfully performed in such ILs-containing media 
(Potdar et al. 2015; Roosen et al. 2008; van Rantwijk and Sheldon 2007). Despite the excellent performance of ILs in biocatalysis, more doubts about their ungreenness and environmental influence have been gradually presented (Zhao et al. 2007; Thuy Pham et al. 2010; Petkovic et al. 2012).

Deep eutectic solvents (DESs), the recognized alternative of ILs, first came to the public vision in 2001 (Abbott et al. 2001). Since then, research on DESs faced a prosperous increase in many fields, such as extraction, materials synthesis, and biotransformation (Atilhan and Aparicio 2016; Carriazo et al. 2012; Dai et al. 2013b; Garcia et al. 2015; Gonzalez-Martinez et al. 2016; van Osch et al. 2015). A brief statistics of the published literature starting form 2004 is presented in Fig. 1. This review will provide an overview of the (un)greenness of DESs and recent applications in biocatalysis. Finally, how DESs affect biocatalytic reactions are discussed.

\section{DESs and their properties DESs}

DESs are eutectic mixtures of salts and hydrogen bond donors (HBDs) with melting point low enough to be used as solvents. A eutectic liquid is generally formed by two solids at eutectic temperature, in which the process follows a thermal equilibrium. A deep eutectic system refers to a eutectic mixture with a melting point much lower than either of the individual components. A classic example is that $\mathrm{ChCl} /$ urea (1:2 mol ratio) mixture has a melting point of $12{ }^{\circ} \mathrm{C}$ (far lower than the melting point of the $\mathrm{ChCl}$ and urea, 302 and $133{ }^{\circ} \mathrm{C}$, respectively), which makes it a liquid to be used as a solvent at room temperature. In addition, the complex hydrogen bonding network existing in DES also makes it a special solvent for different applications (Hammond et al. 2016).

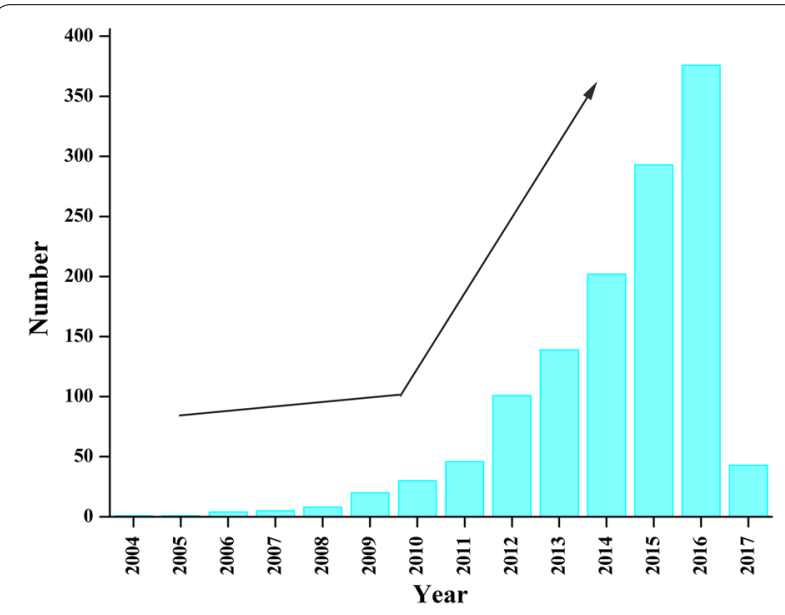

Fig. 1 The number of published papers on DESs starting from 2004 (adapted from ISI Web of Knowledge)
Up to now, many kinds of DESs have been developed with various compounds (Fig. 2). They are generally prepared by mixing a hydrogen bond acceptor (HBA), such as quaternary ammonium salt with a metal salt or HBD at moderate temperature with constant stirring. The first examples of DESs were prepared by heating $\mathrm{ZnCl}_{2}$ with a series of quaternary ammonium salts, in which choline chloride is the HBA obtained at the surprisingly lowest melting point of $23-25^{\circ} \mathrm{C}$ (Abbott et al. 2001). In 2014, Abbott et al. proposed a general formula of $\mathrm{Cat}^{+} \mathrm{X}^{-} z \mathrm{Y}$ for DESs, where $\mathrm{Cat}^{+}$refers to ammonium, phosphonium or sulfonium cation and $\mathrm{X}$ generally represents a halide anion (Smith et al. 2014). This formula represents four classes of DESs according to the nature of the components used.

Class I: $\quad \mathrm{Cat}^{+} \mathrm{X}^{-} z \mathrm{MCl} x, \mathrm{M}=\mathrm{Zn}, \mathrm{Sn}, \mathrm{Fe}, \mathrm{Al}, \mathrm{Ga}$, In. Class II: $\mathrm{Cat}^{+} \mathrm{X}^{-} z \mathrm{MCl} x y \mathrm{H}_{2} \mathrm{O}, \mathrm{M}=\mathrm{Cr}, \mathrm{Co}, \mathrm{Cu}, \mathrm{Ni}, \mathrm{Fe}$. Class III: $\mathrm{Cat}^{+} \mathrm{X}^{-} z \mathrm{RZ}, \mathrm{Z}=\mathrm{CONH}_{2}, \mathrm{COOH}, \mathrm{OH}$.

Class IV: $\mathrm{MCl} x+\mathrm{RZ}=\mathrm{MCl}_{x-\mathrm{I}}^{+} \mathrm{RZ}+\mathrm{MCl}_{x+1}^{-} \mathrm{M}=\mathrm{Al}, \mathrm{Zn}$ and $\mathrm{Z}=\mathrm{CONH}_{2}, \mathrm{OH}$.

The main difference between Class II DESs and I is the inherent water, which makes it possible for many hydrated metal halide salts to be used as HBDs to synthesize DESs, since they have relatively lower cost.

Another set of DESs, "natural deep eutectic solvent (NADES)", are developed by utilizing many primary metabolites, such as amino acids, sugars, choline and organic acid (Choi et al. 2011). NMR-based metabolomics analysis indicated that NADES indeed existed as the third liquid other than water and lipid in an organism. For example, a mixture of sucrose, fructose and glucose (1:1:1, molar ratio) forms a clear and uniform liquid at room temperature. They can help plants survive anhydrobiosis and play a role in the synthesis of intracellular macromolecules. These NADES may preserve the linkage between understanding of cellular metabolism and physiology.

\section{Properties}

DESs have some special physical traits which are very useful for biocatalytic process, i.e., a wide liquid state range, nonflammability and low volatility (Abbott et al. 2011; Paiva et al. 2014; Smith et al. 2014; Zhang et al. 2012). Low temperature of freezing point ( $\mathrm{T} f$ ) makes it possible for DESs to remain as a liquid in a biocatalytic process, because most biocatalytic reactions proceed in a liquid environment, in either monophasic or biphasic system. As reported, the $T_{f}$ of a DES depends on many factors. Increased hydroxyl group of $\mathrm{HBD}$ increased the value of $\mathrm{T}_{f}$ For example, the $\mathrm{HBD}$ in $\mathrm{ChCl} / \mathrm{Gly}$ has three hydroxyl groups and melts at $-40{ }^{\circ} \mathrm{C}$, while the HBD in 


\section{Hydrogen bond acceptors/Halide salts}<smiles>C[N+](C)(C)CCO</smiles><smiles>C[N+](C)(C)CCCl</smiles><smiles>CC[NH+]([ClH+])CCC(C)C(C)(C)Cc1ccccc1</smiles><smiles>CC[NH3+]</smiles><smiles>Br[B-](Br)(Br)[N+](Br)(Br)Br</smiles><smiles>Br[P-](Br)(Br)(Br)Br</smiles><smiles>Br[P-](c1ccccc1)(c1ccccc1)c1ccccc1</smiles>

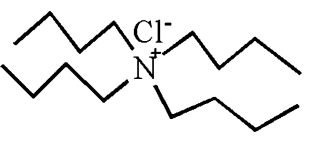

\section{Hydrogen bond donors}<smiles>NC(N)=O</smiles><smiles>CC(N)=O</smiles><smiles>CNC(N)=O</smiles><smiles>NC(N)=S</smiles><smiles>CN(C)C(N)=O</smiles><smiles>NC(=O)c1ccccc1</smiles><smiles>OCCO</smiles><smiles>OCC(O)CO</smiles><smiles>CC(O)C(=O)O</smiles><smiles>O=C(O)C(O)C(O)C(=O)O</smiles><smiles>O=C(O)CC(=O)O</smiles><smiles>O=C(O)C(=O)O</smiles><smiles>O=C(O)CC(O)(CC(=O)O)C(=O)O</smiles><smiles>O=CC(O)C(O)C(O)C(O)CO</smiles><smiles>OCC1OC(OC2(CO)OC(CO)C(O)C2O)C(O)C(O)C1O</smiles><smiles>O=CC(O)C(O)C(O)C(O)CO</smiles><smiles>O=CC(O)C(O)C(O)CO</smiles>

Fig. 2 Examples of chemicals for DESs synthesis

$\mathrm{ChCl} / \mathrm{EG}$ has two hydroxyl groups and melts at $-66{ }^{\circ} \mathrm{C}$ (Zhang et al. 2012). DESs with different mole ratios of HBA to HBD also show different $T_{f}$ but no obvious tendency was observed. The glycerol-based DESs with methyl triphenyl phosphonium bromide as HBA (1:21:4, molar ratio) have a $\mathrm{T}_{f}$ range from -5.5 to $15.8{ }^{\circ} \mathrm{C}$ (Shahbaz et al. 2011). Besides, DESs are commonly not flammable and have very low volatility, because their individual components are generally solids or inflammable liquid. These two properties decrease the risk of explosion and burning for an organic reaction if DESs are used as solvents instead of volatile organic solvents, thus making it safe to operate. What is more, density and viscosity are the other two important characteristics which affect the mass transfer when selecting a solvent for use. Generally, the viscosity of DESs lies in the constitution and is higher than that of the molecular solvent ethanol (Smith et al. 2014). The specific relationship between these factors has been documented at length in another review (Zhang et al. 2012). Most properties change as a function of temperature (Zhao et al. 2015). For instance, as the temperature increases, the density and viscosity decrease.

Two other advantages of DESs over ILs are easier preparation and lower cost. Typical preparation of DESs involves a mixing of the components in a certain 
molar ratio (e.g., 1:2 of HBA/HBD) with constant stirring at moderate temperature. This simple synthesis is $100 \%$ atom economic, requiring no further purification. Besides, the commonly used components of DESs, such as $\mathrm{ChCl}$ and glycerol, are all from natural materials. Especially, NADESs are absolutely formed by primary metabolites, such as glucose, malic acid and succinic acids (Dai et al. 2013a). These raw materials exist naturally and have relatively low cost of production. By contrast, the common preparation of ILs has two steps: first alkylation of an amine/phosphine/sulfide to afford an intermediate salt, followed by anion exchange to give the ILs (Hallett and Welton 2011). The complexity of synthesis will spontaneously increase the production cost. Thus, the synthesis of DESs is easier and costs less than that of ILs.

\section{Toxicity}

A good question about whether DESs are toxic was proposed in 2013 (Hayyan et al. 2013b). The answer for that is some of them are toxic. Most of them are basically soluble in water. Especially in the cases of Class I and Class II DESs, the metal ion will inevitably leave a trace in the environment, thus exerting pressure on recycling these solvents.

To date, only a few groups have investigated the toxicological properties of DESs in detail (Table 1). Hayyan and co-workers first investigated the toxicity and cytotoxicity of $\mathrm{ChCl}$ - and phosphonium-based DESs, of which glycerine, ethylene glycol, triethylene glycol and urea were used as the HBDs (Hayyan et al. 2013a, b). They pointed out that the toxicity and cytotoxicity of different DESs varied with the structure of the components used. ChCl-based DESs were less toxic than phosphonium-based DESs. Afterward, the toxicity of ammoniumbased DESs was evaluated in in vitro cell lines and in vivo animal models (Hayyan et al. 2015). In this study, the DESs tested showed higher toxicity than their individual components,which was consistent with other DESs reported previously. Later, some ternary DESs consisting of $\mathrm{ChCl}$, water and natural substance were also examined for their cytotoxicity (Hayyan et al. 2016). Selection of DESs parents is very important for the toxicity of resulting DESs. The $\mathrm{IC}_{50}$ of $\mathrm{ChCl} / \mathrm{Gly} / \mathrm{H}_{2} \mathrm{O}$ toward Hela S3 cell was almost 2.4-fold higher than that of $\mathrm{ChCl} /$ fructose/ $\mathrm{H}_{2} \mathrm{O}$ (427 $\mathrm{mM}$ vs $177 \mathrm{mM}$ ), though in the former DES Gly had higher concentration (1:2:1 vs 5:2:5, respectively). Glycerol is a wildly used sweetener and humectant in the food industry and used in strain preservation; so the toxicity of glycerol-based DESs is expectable to some degree.

However, the toxic DESs can be used for beneficial purposes, e.g., as effective anti-bacterial agents. The DES choline/geranate can inhibit the growth of some bacteria, fungi and viruses, making it a possible broad-spectrum antimicrobial agent (Zakrewsky et al. 2016).

In our work, a method of bacterial growth inhibition was used to assess the toxicology of four types of DESs based on $\mathrm{ChCl}$, which was coupled with amine-, alcohol-, sugar- and organic acid-based HBDs (Zhao et al. 2015). The organic acid-based DESs significantly inhibited bacterial growth, suggesting the limitation of utilizing organic acid when designing DESs. This finding was in accordance with Hayyan's study, which found that $\mathrm{ChCl} / \mathrm{MA}$ was greatly toxic toward the tested mammalian cells (Hayyan et al. 2016). The other three types of DESs displayed less toxicity to the tested Gram-positive (Staphylococcus aureus and Listeria monocytogenes) and Gram-negative (Escherichia coli and Salmonella enteritidis) bacteria. Interestingly, a further MIC test demonstrated that the two Gram-negative bacteria were less sensitive than Gram-positive bacteria toward the organic acid-based DESs. A mechanism of this difference may be related to the oligosaccharide constituent.

All the examples give us information, that is, reasonable design and post-processing of DESs are very important for us to utilize this solvent. Novel DESs can be made according to the properties of parent components for special use. Some DESs showed toxicity to some extent, but there is limitation for these studies, due to the fact that the tested organisms are different with what we use in a biocatalytic process. For a typical reaction, one can determine the effect of DESs they use on the biocatalyst, under the guidance of previous researches.

\section{Biodegradability}

Biodegradability is another important property except toxicity when talking about the "greenness" of DESs. A large proportion of DESs are considered as "readily biodegradable", possibly because most of the components forming DESs are natural products (Radosevic et al. 2015; Zakrewsky et al. 2016). Taking the NADES, for instance, all the individual components come from natural materials and can be metabolized by different kinds of organisms in nature. Glycerol can enter the pathway of glycolysis or gluconeogenesis for final metabolism and the sugar portion can also be directly utilized (Mbous et al. 2017).

Table 2 shows the recent studies which reported the biodegradability of DESs. In Radosevic's work, the closed bottle test (OECD) was used according to the OECD guideline $301 \mathrm{D}$ (1992D), and all the tested ChCl-based DESs (ChCl:Gly, $\mathrm{ChCl}$ Glc, and $\mathrm{ChCl}: \mathrm{OA}$ ) provided a biodegradation level of over $60 \%$ after 14 days (Radosevic et al. 2015). The highest biodegradability level was observed up to $96 \%$ with $\mathrm{ChCl}$ :Gly. These findings for DES biodegradability were in accordance with our 
Table 1 The toxicity of some DESs

\begin{tabular}{|c|c|c|c|}
\hline DESs & Organism & Toxicity comments & References \\
\hline $\begin{array}{l}\text { MTPB/Gly }(1: 3) \\
\text { MTPB/EG }(1: 3) \\
\text { MTPB/TEG }(1: 3)\end{array}$ & $\begin{array}{l}\text { Escherichia coli, Staphylococcus aureus, Pseu- } \\
\text { domonas aeruginosa, Bacillus subtilis, Artemia } \\
\text { salina }\end{array}$ & $\begin{array}{l}\text { All the DESs showed toxic effect on some } \\
\text { bacteria } \\
\text { The cytotoxicity of DESs was much higher than } \\
\text { their individual components }\end{array}$ & Hayyan et al. (2013a) \\
\hline $\begin{array}{l}\text { ChCl/Gly (1:3) } \\
\text { ChCl/EG (1:3) } \\
\text { ChCl/U (1:3) } \\
\text { ChCl/TEG (1:3) }\end{array}$ & $\begin{array}{l}\text { Escherichia coli, Staphlococcus aureus, Pseu- } \\
\text { domonas aeruginosa, Bacillus subtilis, Artemia } \\
\text { salina }\end{array}$ & $\begin{array}{l}\text { All the DESs showed no toxic effect on the } \\
\text { bacteria } \\
\text { The cytotoxicity of DESs was much higher than } \\
\text { their individual components }\end{array}$ & Hayyan et al. (2013b) \\
\hline $\begin{array}{l}\mathrm{ChCl} / \mathrm{Gly}(1: 3) \\
\mathrm{ChCl} / \mathrm{EG}(1: 3) \\
\mathrm{ChCl} / \mathrm{TEG}(1: 3) \\
\mathrm{ChCl} / \mathrm{U}(1: 3)\end{array}$ & $\begin{array}{l}\text { PC3, A375, HepG2, HT29, MCF-7, OKF6, H413, } \\
\text { ICR mice }\end{array}$ & $\begin{array}{l}\text { The cytotoxicity of DESs varied from various cell } \\
\text { lines. The toxic effects of DESs were higher } \\
\text { than their individual components }\end{array}$ & Hayyan et al. (2015) \\
\hline $\begin{array}{l}\mathrm{ChCl} \text { or ChOAc/U }(1: 1) \\
\mathrm{ChCl} \text { or ChOAc/Gly }(1: 1) \\
\mathrm{ChCl} \text { or ChOAc/A }(1: 1) \\
\mathrm{ChCl} \text { or ChOAc/EG }(1: 1)\end{array}$ & Escherichia coli & $\begin{array}{l}0.75 \mathrm{M} \text { DES could afford an inhibition index of } \\
72.8-93.8 \% \text { for the bacterium and was more } \\
\text { toxic then the components }\end{array}$ & Wen et al. (2015) \\
\hline $\begin{array}{l}\text { ChCl/EG }(1: 2) \\
\text { ChCl/Gly }(1: 2) \\
\text { ChCl/U }(1: 2) \\
\text { DAC/EG }(1: 2) \\
\text { EAC/Gly }(1: 2) \\
\text { DAC/MA }(1: 1) \\
\text { DAC/ZnN }(1: 1) \\
\text { DAC/ZnCl } 2(1: 2)\end{array}$ & Aspergillus niger, Cyprinus carpio fish & $\begin{array}{l}\text { Metal salt-containing DESs were most toxic } \\
\text { than others. DAC-based DESs were less toxic } \\
\text { than ChCl-based DESs }\end{array}$ & Juneidi et al. (2015) \\
\hline 20 kinds of NADESs & $\begin{array}{l}\text { Staphylococcus aureus, Listeria monocytogenes, } \\
\text { Escherichia coli, Salmonella enteritidis }\end{array}$ & $\begin{array}{l}\text { All the DESs except for acid-containing DESs } \\
\text { showed no toxic effect on the bacteria }\end{array}$ & Zhao et al. (2015) \\
\hline $\begin{array}{l}\mathrm{ChCl} / \mathrm{ZnCl}_{2}(1: 2) \\
\mathrm{ChCl} / \mathrm{U}(1: 2) \\
\mathrm{ChCl} / \mathrm{Gly}(1: 3) \\
\mathrm{ChCl} / \mathrm{EG}(1: 3) \\
\mathrm{ChCl} / \mathrm{DEG}(1: 2) \\
\mathrm{ChCl} / \mathrm{TEG}(1: 3) \\
\mathrm{ChCl} / \mathrm{Fru}(2: 1) \\
\mathrm{ChCl} / \mathrm{Gl}(2: 1) \\
\mathrm{ChCl} / \mathrm{PTSA}(1: 3) \\
\mathrm{ChCl} / \mathrm{MA}(1: 1)\end{array}$ & $\begin{array}{l}\text { Phanerochaete chrysosporium, Aspergillus niger, } \\
\text { Lentinus tigrinus, Candida cylindracea }\end{array}$ & $\begin{array}{l}\mathrm{ZnCl}_{2}, \text { PTSA and MA DESs had the most toxic } \\
\text { effect }\end{array}$ & Juneidi et al. (2016) \\
\hline $\begin{array}{l}\mathrm{ChCl} / \text { Fru/water }(5: 2: 5) \\
\mathrm{ChCl} / \mathrm{Gl} / \text { water }(5: 2: 5) \\
\mathrm{ChCl} / \mathrm{Suc} / \text { water }(4: 1: 4) \\
\text { ChCl/Gly/water }(1: 2: 1) \\
\text { ChCl/malonic acid }(1: 1)\end{array}$ & HelaS3, CaOV3, B16F10, MCF-7 & $\begin{array}{l}\text { NADESs except malonic acid as HBD are less } \\
\text { toxic than DESs }\end{array}$ & Hayyan et al. (2016) \\
\hline Choline and geranate $(1: 2)$ & M. tuberculosis, S. aureus, P. aeruginosa et al. & $\begin{array}{l}\text { The DES is so toxic that it can act as a broad- } \\
\text { spectrum antiseptic agent }\end{array}$ & Zakrewsky et al. (2016) \\
\hline $\begin{array}{l}\text { ChCl/Fru }(2: 1) \\
\text { ChCl/GlC }(2: 1) \\
\text { DAC/TEG }(1: 3)\end{array}$ & HelaS3, PC3, AGS, A375, MCF-7, WRL-68 & $\begin{array}{l}\text { The DESs (ChCl/Fru and } \mathrm{ChCl} / \mathrm{Glc} \text {, } \\
\left.98 \mathrm{mM} \leq \mathrm{EC}_{50} \leq 516 \mathrm{mM}\right) \text { were less toxic } \\
\left.\text { than DAC/TEG(34 } \mathrm{mM} \leq \mathrm{EC}_{50} \leq 120 \mathrm{mM}\right)\end{array}$ & Mbous et al. (2017) \\
\hline
\end{tabular}

study, in which all the ChCl-based DESs had degradability of over $69.3 \%$ after 28 days (Zhao et al. 2015). However, Wen et al. found a different conclusion (Wen et al. 2015). They found that only two $(\mathrm{ChCl} / \mathrm{U}$ and $\mathrm{ChCl} / \mathrm{A})$ of the eight DESs tested could be regarded as readily biodegradable. The two DESs showed a degradability close to $80 \%$; nevertheless, the others provided a degradability below $50 \%$ in contrast. In the same year, Juneidi et al. also presented a comprehensive study on the biodegradability for cholinium-based DESs (Juneidi et al. 2015). It is worth mentioning that this work involved in the toxicity and biodegradability of DESs-containing a metal salt and a hydrated metal salt (i.e., $\mathrm{ZnCl}_{2}$ and $\mathrm{ZnN}$ ). There was a significant difference between the degradability of DAC: $\mathrm{ZnN}$ and DAC: $\mathrm{ZnCl}$ (about $80 \%$ vs $62 \%$ ). Even the biodegradability of the former was better than that of the conventional IL [BMPyr] $\left[\mathrm{NTf}_{2}\right]$ (77\%). The inherent structure of HBAs and HBDs is the basic factor which determines the biodegradability of different DESs, i.e., the number of hydroxy groups (Radosevic et al. 2015). 
Table 2 The biodegradability of some DESs

\begin{tabular}{|c|c|c|c|c|c|}
\hline DESs & Assay method & Resource of microorganism & $\begin{array}{l}\text { DES concentration } \\
\text { (mg/L) }\end{array}$ & Comments & Reference \\
\hline $\begin{array}{l}\mathrm{ChCl} / \mathrm{Glc}(2: 1) \\
\mathrm{ChCl} / \mathrm{OA}(1: 1) \\
\text { ChCl/Gly }(1: 2)\end{array}$ & Closed bottle test & $\begin{array}{l}\text { Effluent from an urban } \\
\text { wastewater treatment plant }\end{array}$ & 100 & $\begin{array}{l}\text { Over } 60 \% \text { of biodegrada- } \\
\text { tion level after } 14 \text { days }\end{array}$ & Radosevic et al. (2015) \\
\hline 20 kinds of NADESs & Closed bottle test & Fresh lake water & 3 & $\begin{array}{l}\text { All DESs had a biodegra- } \\
\text { dation level over 69.3\% } \\
\text { after } 28 \text { days. The } \\
\text { acid-based DESs were } \\
\text { degraded slower than } \\
\text { others }\end{array}$ & Zhao et al. (2015) \\
\hline $\begin{array}{l}\mathrm{ChCl} \text { or ChOAc/U }(1: 1) \\
\mathrm{ChCl} \text { or ChOAc/Gly }(1: 1) \\
\mathrm{ChCl} \text { or ChOAc/A }(1: 1) \\
\mathrm{ChCl} \text { or ChOAC/EG }(1: 1)\end{array}$ & Closed bottle test & $\begin{array}{l}\text { Activated sludge from waste- } \\
\text { water treatment plant }\end{array}$ & 4 & $\begin{array}{l}\text { Only } \mathrm{ChCl} / \mathrm{U} \text { and } \mathrm{ChCl} / \mathrm{A} \\
\text { were readily biode- } \\
\text { gradable }\end{array}$ & Wen et al. (2015) \\
\hline $\begin{array}{l}\text { ChCl/EG }(1: 2) \\
\text { ChCl/Gly }(1: 2) \\
\text { ChCl/U }(1: 2) \\
\text { DAC/EG }(1: 2) \\
\text { EAC/Gly }(1: 2) \\
\text { DAC/MA }(1: 1) \\
\text { DAC/ZnN }(1: 1) \\
\text { DAC/ZnCl } 2(1: 2)\end{array}$ & Closed bottle test & $\begin{array}{l}\text { Wastewater from secondary } \\
\text { effluent treatment plant }\end{array}$ & 5 & $\begin{array}{l}\text { All DESs were referred } \\
\text { to as readily biode-- } \\
\text { gradable. ChCl-based } \\
\text { DESs had higher } \\
\text { biodegradability than } \\
\text { DAC-based DESs }\end{array}$ & Juneidi et al. (2015) \\
\hline
\end{tabular}

For a special DES, the difference in result between various reports should be attributed to the difference of the measure condition, the molar ratio of DESs and the wastewater microorganisms.

In summary, DESs exhibit relatively low toxicity toward organisms in a laboratory scale and could be classified as biodegradable green solvents. These benign characteristics may attract more attention of researchers to shift from the classical imidazolium and pyridinium ILs to DESs. More organic chemistry reactions could be explored in such solvents.

\section{The application of DESs in biocatalysis}

Recent decades have witnessed the dramatic publications of ILs in chemical synthesis with isolated enzymes or whole cells (Wang et al. 2012). By comparison, only dozens of studies about the biocatalysis in DESs have been published. The following parts will introduce the recent applications of DESs in biocatalytic reactions, in which DESs played different roles such as solvent, co-solvent or substrate.

\section{DESs as solvent for enzyme catalysis}

As a new generation of solvent, DESs have distinctive characteristics, e.g., abundant hydrogen bond and low $\mathrm{T}_{f}$ The components of DESs may display inhibitory effect on enzyme activity. For example, urea could induce the unfolding of enzymes and further make them inactive (Attri et al. 2011). Even so, some hydrolases still exhibited better activity in DES compared with ILs and catalyzed a lot of hydrolysis and transesterification reactions as well as Henry reaction and aldol reaction in this special solvent.

\section{Lipase}

Lipases, which are commonly investigated in an organic environment, are the popular choices for enzymatic reaction carried out in DESs (Table 3). In 2008, Kazlauskas et al. first tried the lipase-catalyzed biotransformation reaction in DESs (Fig. 3) (Gorke et al. 2008). Four lipases (iCALB, CALB, CALA and PCL) were investigated for their transesterification activity in eight DES-containing systems. In glycerol-containing DESs, all the enzymes showed conversions of ethyl valerate to varying degrees. Especially in $\mathrm{ChCl} / \mathrm{Gly}$, PCL exhibited the lowest conversion (22\%), still much higher than that in toluene (5.0\%). Interestingly, the alcohol component, either ethylene glycol or glycerol, could compete with 1-butanol. When the concentration of the substrate 1-butanol was much lower than the EG component (400 $\mathrm{mM}$ vs $10 \mathrm{M})$, the CALB-catalyzed reaction still displayed a nearly equal amount of product esters. The reason for this may be the high hydrogen bond network, which hinders the reaction of the alcohol components with the substrate. Additionally, the iCALB exhibited great aminolysis activity in ChCl:Gly-containing system $\left(52 \mu \mathrm{mol} \mathrm{h}^{-1} \mathrm{mg}^{-1}\right)$, which was five times higher than in $\operatorname{BMIM}\left[\mathrm{BF}_{4}\right]$ $\left(9 \mu \mathrm{mol} \mathrm{h}{ }^{-1} \mathrm{mg}^{-1}\right)$. This example opened the possibilities for exploring various biocatalytic reactions in DES-containing solvents. 


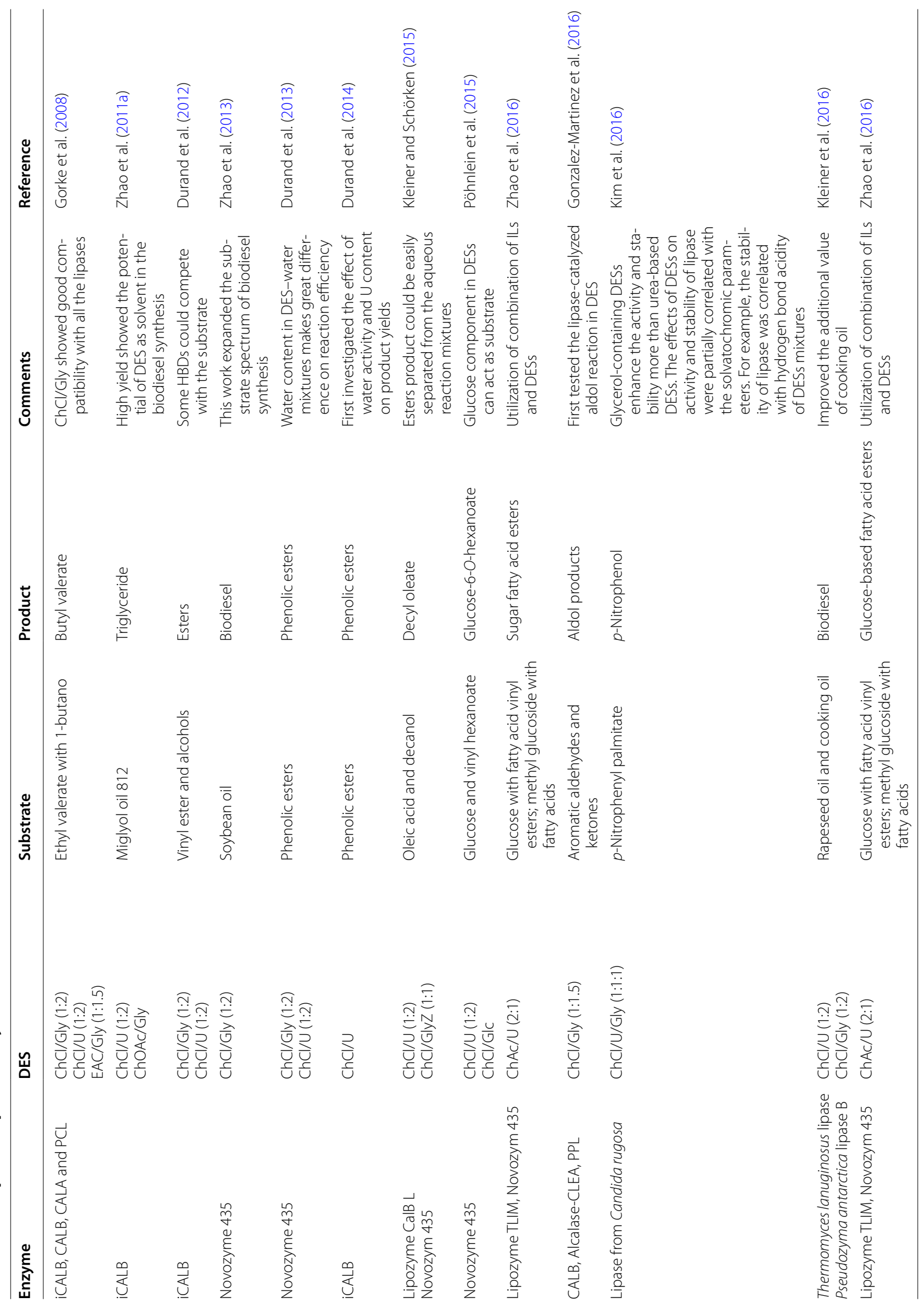




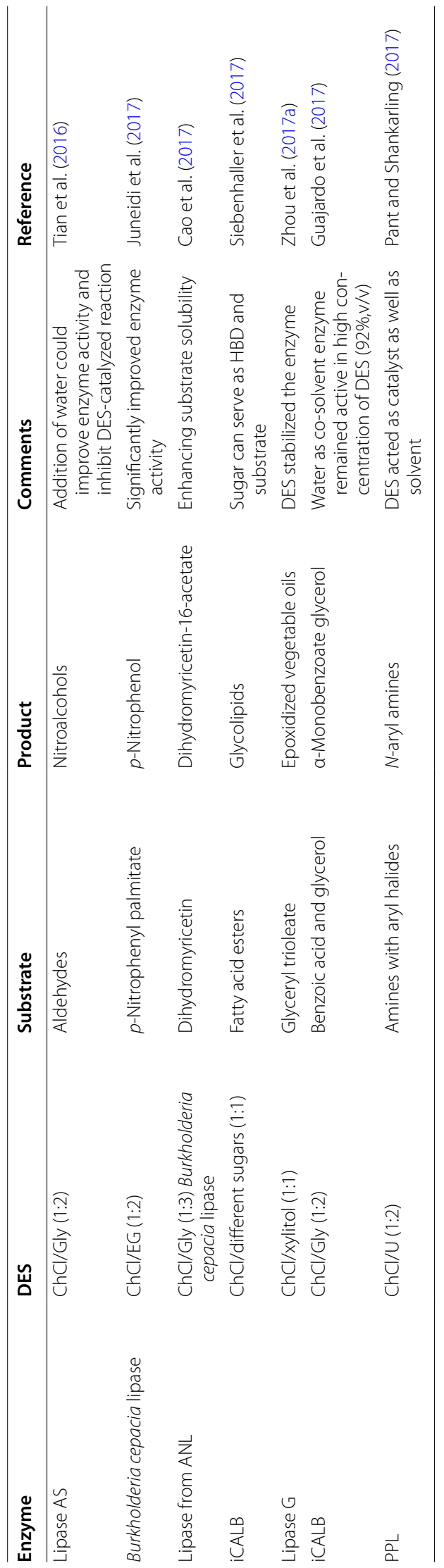




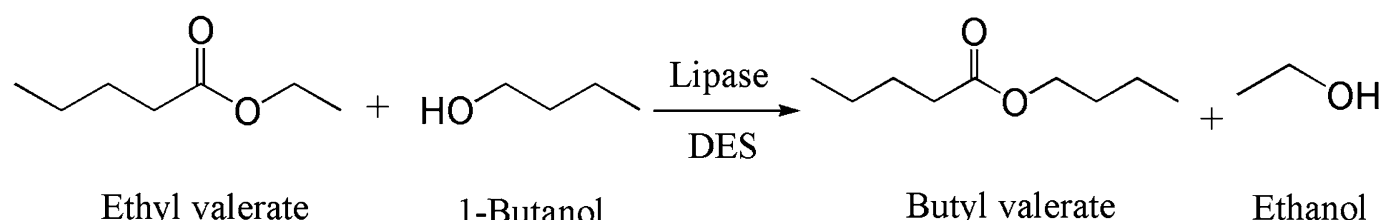

Lipase $=i$ CALB, CALB, CALA, PCL

$\mathrm{DES}=\mathrm{ChCl} / \mathrm{EG}(1: 2), \mathrm{ChCl} / \mathrm{Gly}(1: 2), \mathrm{ChCl}: \mathrm{U}(1: 2), \mathrm{DAC} / \mathrm{Gly}(1: 1.5)$

Fig. 3 Lipase-catalyzed transesterification of ethyl valerate to butyl valerate in DESs (adapted from Gorke et al. 2008)

In a following research by Durand (2012), the iCALBcatalyzed transesterification of vinyl ester was used to study the advantages and limitations of seven kinds of DESs (Fig. 4). The same competing phenomenon was observed between the DES component and the alcoholysis reaction. When the reaction occurred in $\mathrm{ChCl}: \mathrm{U}$ or ChCl:Gly-containing system, alcohol substrate with different chain lengths showed no influence on the conversion and selectivity. A preliminary grinding of the immobilized enzymes could improve specific surface area in DESs, enhancing the reaction efficiency. Recently, they has intended to improve the lipase-catalyzed reaction efficiency in ChCl-based DESs (Durand et al. 2014). As mentioned earlier, albeit the liquid state of DESs at room temperature, their viscosity should be considered for the mass transfer once being used in a biocatalytic reaction. In this work, the effect of water content and urea concentration was systematically assessed. The thermodynamic activity of water $\left(a_{\mathrm{w}}\right)$ was used as the study object. When the $\mathrm{ChCl} /$ water was lower than 1.75 in the ternary mixture, water trended to be bound to the salt and could not affect the lipase activity. In cases of higher $a_{\mathrm{w}}$, excess water molecules could affect its role as the solvent, leading to the occurrence of side reactions. When the water content in the mixture was 1 and $1.5 \mathrm{~mol}$, the urea content showed no significant effect on the lipase stability. However, the denaturation effect of urea increased with the increase of urea content at higher water content.
In some cases, DES can play a bifunctional role, that is, substrate and solvent, in lipase-catalyzed reactions. Several DESs with sugars (e.g., arabinose, xylose, glucose and mannose) as HBD was used as substrate other than solvent to form glycolipid, which was detected by MS-based methods (Fig. 5) (Siebenhaller et al. 2017). This approach of using DESs exhibits an apparent advantage that high concentration of the sugar substrate can push the reaction forward in the product direction.

Lipase-catalyzed promiscuous reactions, such as carbon-carbon bond formation, Henry and Aldol reactions, have attracted some groups' attention (Gonzalez-Martinez et al. 2016; Guan et al. 2015; Tian et al. 2016; Zhou et al. 2017b). Gonzalez-Martinez and co-workers investigated the lipase-catalyzed aldol reactions in DES-containing system in 2016 (Gonzalez-Martinez et al. 2016). A model reaction between 4-nitrobenzaldehyde and acetone was set up to examine the feasibility of DES as a reaction medium for the promiscuous aldol process (Fig. 6a). Three hydrolases, CALB, Alcalase-CLEA and PPL, were explored. Compared to the other two enzymes, PPL displayed great activity at different reaction temperatures $\left(30-60{ }^{\circ} \mathrm{C}\right)$ in a system containing $\mathrm{ChCl}$ :Gly. The ratio of $\mathrm{ChCl}$ to Gly (1:1.5 or 1:2, molar ratio) posed little effect on the conversion and product composition. For this, the ratio was not probably the main aspect that affected the reaction efficiency under the optimized conditions. Different mole ratios of the HBA to HBD may

$$
\begin{aligned}
& \mathrm{R}_{1}=\mathrm{C}_{11} \mathrm{H}_{23}, \mathrm{R}_{2}=\mathrm{C}_{4} \mathrm{H}_{9}, \mathrm{C}_{8} \mathrm{H}_{17}, \mathrm{C}_{18} \mathrm{H}_{37} \\
& \mathrm{DES}=\mathrm{ChCl} / \mathrm{U}(1: 2), \mathrm{ChCl} / \mathrm{Gly}(1: 2), \mathrm{ChCl} / \mathrm{OA}(1: 1), \mathrm{ChCl} / \mathrm{MA}(1: 1), \mathrm{ChCl} / \mathrm{EG}(1: 2), \mathrm{DAC} / \mathrm{U}(1: 2), \mathrm{DAC} / \mathrm{Gly}(1: 2) \\
& \text { Fig. } 4 \text { Lipase-catalyzed transesterification of vinyl ester in DESs (adapted from Durand et al. 2012) }
\end{aligned}
$$




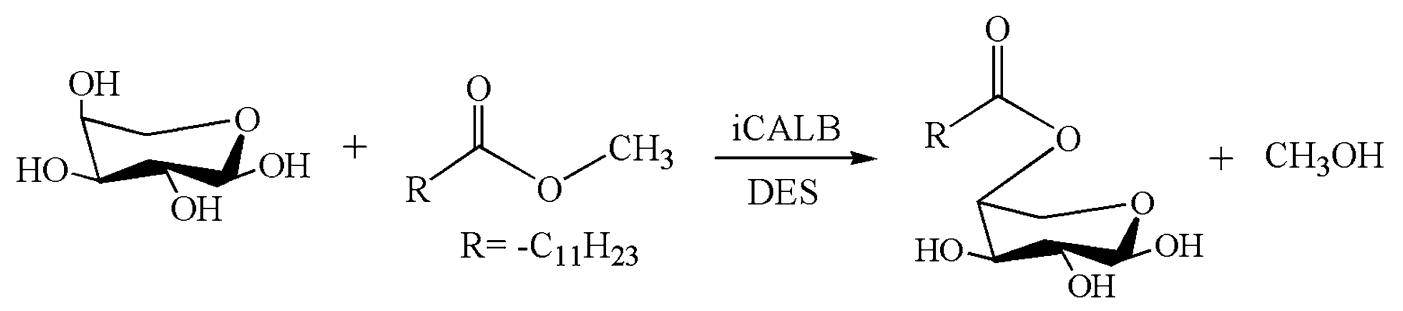

$\mathrm{DES}=\mathrm{ChCl} /$ arabinose, xylose, glucose, mannose, rhamnose

Fig. 5 Lipase-catalyzed production of glycolipids in DESs (adapted from Siebenhaller et al. 2017)<smiles>CC(=O)CC(O)c1ccc([N+](=O)[O-])cc1</smiles>

Hydrolase $=$ CALB, Alcalase-CLEA, PPL

b<smiles>CN(C(=O)[O-])[N+](=O)[O-]</smiles>

\section{Lipase $=$ lipase from Aspergillus niger \\ $\mathrm{DES}=\mathrm{ChCl} / \mathrm{Gly}, \mathrm{ChCl} / \mathrm{EG}, \mathrm{ChCl} / \mathrm{U}$ with different molar ratio}

Fig. 6 Lipase-catalyzed promiscuous reactions in DESs (adapted from (a) Gonzalez-Martinez et al. 2016; (b) Tian et al. 2016)

change the hydrogen bonding formation, further leading to the change of the stereochemical structure of the enzyme, which affects the reaction in turn. Secondly, they tested the suitability of the ChCl:Gly-containing system by exploring different substrate groups, i.e., substituted benzaldehydes with acetone, cyclopentanone and cyclohexanone. In most cases, satisfactory results were obtained. At the same year, Tian et al. explored the Henry reaction catalyzed by lipase AS in $\mathrm{ChCl} / \mathrm{Gly}(1: 2)$-containing media (Fig. 6b) (Tian et al. 2016). Water as a co-solvent was important in the reaction, not only improving enzyme activity, but also inhibiting spontaneous reaction. More recently, a chemoenzymatic epoxidation of alkenes catalyzed by CALB was reported. $\mathrm{DES}, \mathrm{ChCl} /$ sorbitol, efficiently stabilized the biocatalyst, allowing the enzyme to remain active in an oxidative solvent system (Zhou et al. 2017b). The idea of trying lipase-catalyzed promiscuous reaction is of great significance to discover new functions for enzymes in DESs and synthesize many valuable chemicals.

\section{Protease}

Proteases also find promising applications in DESscontaining systems. To explore the feasibility of DES in biocatalysis, Zhao and co-workers evaluated the protease-catalyzed transesterification activities in glycerolbased DESs based on choline salt (chloride or acetate form) (Fig. 7a) (Zhao et al. 2011b). This work indicated again the key role of water in the reaction system. While water content increased from $2 \%(\mathrm{v} / \mathrm{v})$ to $4 \%$, the activity of immobilized subtilisin exhibited a remarkable 1.8-fold 
increase (from 0.50 to $0.90 \mu \mathrm{mol} \mathrm{min} \mathrm{m}^{-1}$ ) in choline acetate/glycerol (1:1.5). This phenomenon was more obvious for immobilized $\alpha$-chymotrypsin. Under reaction conditions with addition of water to the DESs solution, the biocatalytic efficiencies of these two proteases were better than those in $t$-butanol. Apparently, certain DES could activate the protease activity to some extent. This report also demonstrated that immobilization materials could function with water molecules to lower $a_{\mathrm{w}}$ to stabilize the forward reaction.

Except transesterification reaction, proteases-catalyzed peptides synthesis in DESs also proved to be successful. Different $\mathrm{ChCl}$-based DESs using glycerol, urea, xylitol and isosorbide as HBDs were used as solvents for the production of peptides catalyzed by $\alpha$-chymotrypsin (Maugeri and Leitner 2013). High productivities of $20 \mathrm{~g} \mathrm{~L}^{-1} \mathrm{~h}^{-1}$ were afforded at the optimal conditions with $\mathrm{ChCl} /$ glycerol and addition of $10-30 \%(\mathrm{v} / \mathrm{v})$ water. The $\alpha$-chymotrypsin showed good recycling ability in this DES solution system. Recently, the immobilized papain on a magnetic material was successfully used for the synthesis of $\mathrm{N}$-(benzyloxycarbonyl)-alanyl-glutamine (Z-Ala-Gln) in $\mathrm{ChCl} /$ urea (1:2) as well, the yield of which reached about $71.5 \%$ (Fig. 7b) (Cao et al. 2015). In this example, more glutamine (Gln) dissolved in DES buffer remarkably improved the yield and a high Gln/Z-AlaOMe ratio of 3-4 could effectively inhibit the side reaction to form Z-Ala-OH.

\section{Epoxide hydrolase}

Epoxide hydrolases $(\mathrm{EH})$, another important hydrolase, catalyze the enantioselective hydrolysis of epoxides to the corresponding diols, which are important chiral synthetic intermediates. Up to now, there are only two examples of using DES in EH-catalyzed reactions. The first example was reported in 2008 (Gorke et al. 2008). By the addition of $25 \%(\mathrm{v} / \mathrm{v}) \mathrm{ChCl} / \mathrm{Gly}$ to the buffer, the conversion of styrene oxide catalyzed by EHAD1 increased from 4.6 to $92 \%$. No change in the enantioselectivity was observed with the increase of conversion. The other one was carried out by Widersten et al. (Fig. 8) (Lindberg et al. 2010). Ethane diol, glycerol and urea were used as the hydrogen bond donors. The DES $\mathrm{ChCl} / \mathrm{Gly}$ still exhibited a superior solvent property for this reaction than the other two DESs. Surprisingly, the regioselectivity of this hydrolysis reaction varied with the alteration of solvents. More

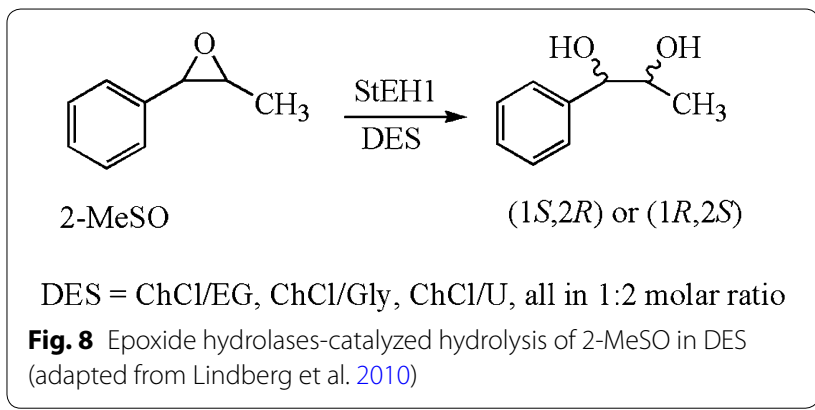<smiles>CCOC(=O)[C@H](Cc1ccccc1)NC(C)=O</smiles>

Protease $=$ Subtilisin on chitosan, free or immobilized a-chymotrypsin on chitosan $\mathrm{DES}=\mathrm{ChCl} / \mathrm{Gly}(1: 2), \mathrm{ChAc} / \mathrm{Gly}(1: 1.5)$

b<smiles>COC(=O)C(C)NC(=O)OCc1ccccc1</smiles><smiles>CC(NC(=O)OCc1ccccc1)C(=O)NC(=O)CCC(N)C(=O)O</smiles>

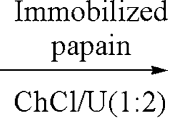
Z-Ala-Gln $\mathrm{MeOH}$

Fig. 7 Protease-catalyzed reactions in DESs (adapted from (a) Zhao et al. 2011b) (b) Cao et al. 2015; 
amounts of $(1 R, 2 R)$-2-MeSO (2-methylstyrene oxide) diols were produced when the diol-and triol-containing DESs were added into the buffer as co-solvents, while the effect of glycerol on the StEH1 catalysis was the least. Many researchers considered that the decrease of enzymatic efficiency in higher ILs concentrations could be attributed to the denaturation of enzyme. However, in this work, the authors proposed that higher DES concentrations could cause the destabilization of enzyme-substrate or reaction intermediate complexes according to steady-state kinetic parameters of StEH1 at different DES concentrations. In addition, the substance concentration with the addition of DES had a 1.5-fold improvement compared to the DES-free buffer. This enhancement, to some degree, was related to the hydrogen bond in the solvent environment. The excellent dissolution-promoting ability of DES has already been used in nature product extraction (Dai et al. 2013b).

\section{Other enzymes}

In other examples of enzymatic reactions, many enzymes, such as haloalkane dehalogenases (Stepankova et al. 2014), benzaldehyde lyase (Maugeri and Domínguez de María 2014) and phospholipase D (Yang and Duan 2016), also showed improved reaction efficiency in the DES-containing system (Table 4). For the diglycosidase from Acremonium sp. DSM24697, the deglycosylation of hesperidin happened when $\mathrm{ChCl}$ combined with urea, glycerol and ethylene glycol was added into the buffer, whereas the enzyme activity was inhibited by DES to some extent (Weiz et al. 2016). The apparent advantage of this approach is the enhanced substrate solubility by DES. Such a property has been successfully applied in the extraction of the natural product [e.g., flavonoid (Zhao et al. 2015) and grape skin phenolics (Cvjetko Bubalo et al. 2016)]. This case is beneficial for the modification of many natural products, which have good solubility in DES.

\section{DES as solvent for whole-cell biocatalysis}

Whole-cell biocatalysis using bacteria or fungi as catalyst, e.g., Acetobacter sp. and recombinant Saccharomyces cerevisiae, has been successfully applied in some organic reactions (Gangu et al. 2009; Wachtmeister and Rother 2016; Xu et al. 2016). In comparison with isolated enzymes, whole-cell catalysts, either in the form of natural organisms or genetically recombinant strains, have a series of advantages, such as lower cost than purified enzymes (Tufvesson et al. 2011), perfect cofactor regeneration system (Hummel and Gröger 2014), applicability in untraditional media (Dennewald and Weuster-Botz 2012) and feasibility of multi-step cascade reactions in one cell (Chen et al. 2015; Peters et al. 2017).
Generally, a monophasic system forms when DES is added to aqueous buffer due to its good solubility in water. As a result, the DES-containing medium will serve as an efficient buffer system for a whole cell-catalyzed process. DES can improve, to some degree, the substrate concentration in the reaction system and further increase the reaction efficiency.

The first example of whole-cell biocatalysis in DES was the reduction of ethyl acetoacetate catalyzed by baker's yeast (Fig. 9) (Table 5) (Maugeri and de Maria 2014). The yeast worked well when $\mathrm{ChCl} / \mathrm{Gly}$ (1:2) was added into an aqueous buffer, and even enantioselectivity had a complete inverse when altering the proportion of DES used. The tested $\mathrm{ChCl} /$ Gly may go into the cell and inhibit the enantioselective enzyme activity or affect the configuration of partial enzymes. A similar enantioselectivity inversion by the addition of DES was further expanded to a series of arylpropanone substrates (Vitale et al. 2016). Both the examples used wild-type baker's yeast as a biocatalyst. It is worth understanding how DESs affect the intracellular enzymes. Recombinant $E$. coli cells expressing oxidoreductases were also investigated for their catalytic reduction of ketones in DES-containing system (Muller et al. 2015). The cells performed surprisingly even in an $80 \%(\mathrm{v} / \mathrm{v})$ DES-containing system for a broad range of aromatic substrates (Fig. 10).

In short, genetically modified recombinant hosts overexpressing different kinds of enzymes with different functions, especially ketoreductase ( $\mathrm{Ni}$ and $\mathrm{Xu} 2012)$, open the way to the industrial production of many valuable compounds. The cost-effective, nonhazardous DESs will present greatly stimulative potential in these biocatalytic processes.

\section{DES as extractive agents in biotransformation}

The separation of the product or unreacted substrate from a reaction should be considered in an industrial catalytic process, especially the biocatalytic reaction, regardless of the utilization of isolated or immobilized biocatalyst. DESs also show great ability to separate the desired compounds from a reaction mixture. Many products are traditionally extracted using organic liquids, such as ethyl acetate, $n$-butyl alcohol, $n$-hexane and isopropyl ether.

As mentioned earlier, DESs are often biomass derived and formed by mixing of $\mathrm{ChCl}$ and a hydrogen bond donor. Krystof et al. (2013) successfully separated 5-hydroxymethylfurfural (HMF) esters with HMF after the lipase-catalyzed (trans)esterification reaction, which exhibited a hydrogen donor character by using $\mathrm{ChCl}-$ based DES. High ester purity ( $>99 \%$ ) and efficiency (up to $>90 \%$ HMF ester recovery) were observed. This finding paved a new path for the HMF chemistry. Inspired by that, ChCl-based DES was also utilized by Qin et al. 


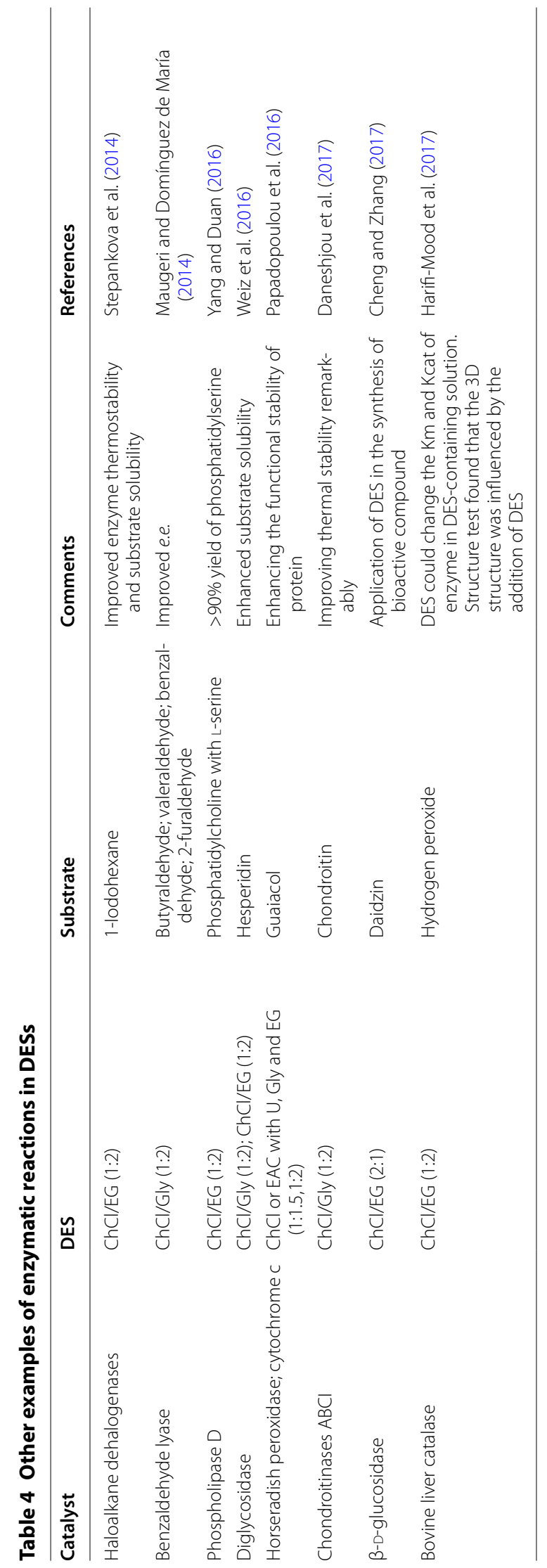




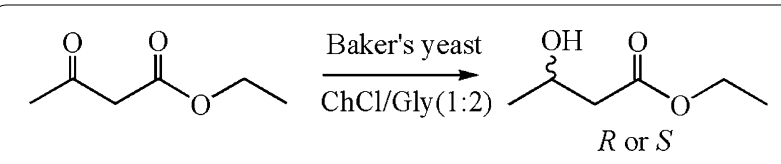

Fig. 9 Baker's yeast-catalyzed reduction reaction in DESs (adapted from Maugeri and de Maria 2014)

to separate HMF and 2,5-diformylfuran (DFF) from the reaction mixtures, and the purity of the latter reached up to $97 \%$ (Qin et al. 2015). The two examples discussed above to some extent were based on the characteristics of the hydrogen bond donor of the separated chemical compounds. Maybe, the formation of a new hydrogen bond existed between the DES and target compounds.

Hydrophobic DES containing quaternary ammonium salt/decanoic acid mixture could extract volatile carboxylic acids from aqueous solution (van Osch et al. 2015). The DESs extracted acetic acid, propionic acid and butyric acid more efficiently than a traditional solvent like trioctylamine. For example, DecA: $\mathrm{N}_{8881}-\mathrm{Cl}$ extracted twice as much acetic acid as trioctylamine $(38.0 \%$ vs 18.6\%). DecA: $\mathrm{N}_{7777^{-}} \mathrm{Cl}$ extracted $91.5 \%$ of the butyric acid. This kind of DES costs less than some ammonium and phosphonium ionic liquids for extracting butyric acid (Blahušiak et al. 2013; Marták and Schlosser 2016). However, another challenge about the separation of acid from DES is put forward subsequently. The traditional distillation method could facilitate the process owing to the extremely low volatility and high thermal stability of DESs (Wu et al. 2015).

\section{DESs function in biomass pretreatment}

DES pretreatment of biomass is a good alternative of IL-based processes. Currently, most attention has been focused on the use of ILs, especially imidazole- and choline-based ILs (Sheldon 2016), for preprocessing cellulose-based biomass to improve the following enzymatic hydrolysis process indirectly. DESs are able to dissolve biopolymers like polysaccharides by breaking the supermolecular structure formed by intermolecular hydrogen bonds (Ren et al. 2016). For example, $\mathrm{ChCl} /$ imidazole can be used to pretreat corncob at a relatively low temperature of $80{ }^{\circ} \mathrm{C}$ and the final glucose yield reached $92.3 \%$ after the enzymatic hydrolysis (Procentese et al. 2015). Due to the diversity of HBDs, researchers have more choice of using different HBDs in conjunction with $\mathrm{ChCl}$ for pretreatment; thus, different results are obtained normally, even for the same biomass like corncob (Zhang et al. 2016). Considering the relative cheapness of ILs, it is useful to develop more cellulase-compatible DESs, making it possible to omit the separation of DESs from the system.

\section{Influence of DESs on biocatalysis}

As shown in the last chapter, many positive examples show the great promising future of DESs in biocatalysis. It is of interest to elucidate under what circumstances and how the biocatalysts retain their biological function and stability in DESs.

\section{Effect of the characteristics of DESs on the biocatalytic process}

The tunability of DES contributes to much more possibility of designing vast kinds of DES, thus bringing various effect on a biocatalytic reaction system. The selection of HBAs and HBDs make a big difference in the whole process. For instance, $\mathrm{ChCl} / \mathrm{Gly}$ is usually used as a good solvent/co-solvent for enzymatic reaction, while the performance of $\mathrm{ChCl} / \mathrm{MA}$ is not satisfactory (Durand et al.

Table 5 Examples of whole-cell biocatalytic reactions in DES

\begin{tabular}{|c|c|c|c|c|c|}
\hline Microbial & DES & Substrate & Product & Comments & References \\
\hline Baker's yeast & ChCl/Gly (1:2) & Ethyl acetoacetate & $\begin{array}{l}\text { Ethyl 3-hydroxybu- } \\
\text { tyrate }\end{array}$ & $\begin{array}{l}\text { Increasing the DES content switched } \\
\text { the enantioselectivity }\end{array}$ & $\begin{array}{l}\text { Maugeri and de } \\
\text { Maria (2014) }\end{array}$ \\
\hline $\begin{array}{l}\text { Acetobacter sp. CCTCC } \\
\text { M209061 }\end{array}$ & $\mathrm{ChCl} / \mathrm{U}(1: 2)$ & $\begin{array}{l}\text { 3-Chloropropiophe- } \\
\text { none }\end{array}$ & $\begin{array}{l}\text { (S)-3-Chloro-1-phe- } \\
\text { nylpropanol }\end{array}$ & $\begin{array}{l}\text { Combination of ILs and DESs in the } \\
\text { biphasic system effectively improved } \\
\text { the substrate concentration }\end{array}$ & Xu et al. (2015) \\
\hline $\begin{array}{l}\text { Recombinant E. coli over- } \\
\text { expressing ADH }\end{array}$ & ChCl/Gly (1:2) & Ketones & Alcohols & $\begin{array}{l}\text { The e.e. of many aromatic substrates } \\
\text { increased by the addition of DES }\end{array}$ & Muller et al. (2015) \\
\hline Baker's yeast & ChCl/Gly (1:2) & $\begin{array}{l}\text { Aryl-containing } \\
\text { ketones }\end{array}$ & $\begin{array}{l}\text { Aryl-containing } \\
\text { alcohols }\end{array}$ & $\begin{array}{l}\text { (S)-oxidoreductases of baker's yeast } \\
\text { was possibly inhibited by DES }\end{array}$ & Vitale et al. (2016) \\
\hline $\begin{array}{l}\text { Recombinant E. coli } \\
\text { CCZU-T15 }\end{array}$ & ChCl/Gly (1:2) & $\begin{array}{l}\text { 4-chloro-3-oxobu- } \\
\text { tanoate }\end{array}$ & $\begin{array}{l}\text { (S)-4-chloro-3-hy- } \\
\text { droxybutanoate }\end{array}$ & $\begin{array}{l}\text { Addition of Tween-80 improved } \\
\text { significantly substrate concentration } \\
\text { from } 2 \text { to } 3 \mathrm{M}\end{array}$ & Dai et al. (2017) \\
\hline $\begin{array}{l}\text { Lysinibacillus fusiformis } \\
\text { CGMCC } 1347\end{array}$ & $\begin{array}{l}\text { ChOAc/U }(1: 1) \\
\text { ChOAc/EG }(1: 1) \\
\text { ChCl/Lac }(4: 1) \\
\text { ChCl/Raf }(11: 2)\end{array}$ & Isoeugenol & Vanillin & $\begin{array}{l}\text { NADESs were first used in whole-cell } \\
\text { biocatalysis }\end{array}$ & Yang et al. (2017) \\
\hline
\end{tabular}




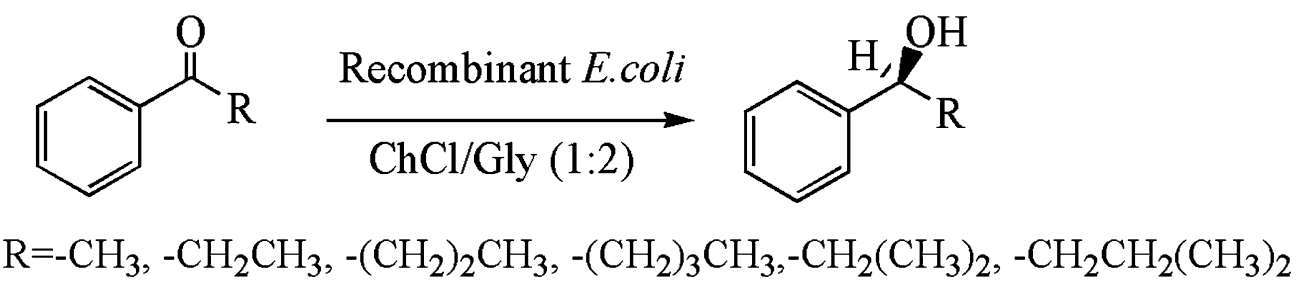

Fig. 10 Recombinant E. coli-catalyzed reduction reactions in DES (adapted from Muller et al. 2015)

2012). Different HBDs also form DESs with different viscosities (Zhang et al. 2012), which affects the mass transfer of all the reactants (substrate, product, catalyst, etc.) and further changes the reaction rate. At this point, the hydrogen bond is another concern posed by various HBDs. There is a difference of just one hydroxyl group between Gly and EG; however, the resulting DESs showed remarkable difference on the lipase-catalyzed reaction (Durand et al. 2012).

Hydrogen bonding of DESs is the main power which makes them distinctive with their individual components. This special force can activate the enzyme by increasing the enzyme affinity with the substrate (Juneidi et al. 2017). It is also necessary to consider the ratio of HBA/ HBD, which might affect the solvatochromic parameters and the hydrogen bond formation between the reaction mixtures (Kim et al. 2016). A molecular dynamics simulation of lipase in $\mathrm{ChCl} / \mathrm{U}$ firstly proved that the hydrogen bond between DES components could hinder the attack of $U$ to the enzyme function domains, thus resulting in a stabilized enzyme (Monhemi et al. 2014).

In addition, DES concentration and water content are two interacting factors with significant influence on the reaction efficiency. A high amount of water not only decreased the viscosity of the DES solution, but also enabled the contact between the enzyme molecule and substrate (Guajardo et al. 2017). But too much water might have a destructive effect on the hydrogen bond network of DES and weaken the benefit of DES.

\section{Influence of DESs on biocatalyst structure and activity}

Firstly, DESs can change the secondary structure of enzymes. Take the horseradish peroxidase (HRP) for example (Wu et al. 2014): higher HBD molar ratio (e.g., from 2:1 to 1:2) in ChCl-based DES increased the $\alpha$-helix content in the HRP. More $\alpha$-helix and less $\beta$-sheet in the structure were beneficial for their activity and stability. The improvement in activity may result from the looser tertiary structure of HRP. A recent report confirmed that the $\mathrm{ChCl}$ component had a disruptive influence on the $\alpha$-helix, which would cause a decrease of the enzyme activity. However, the glycerol component could markedly increase the $\alpha$-helix content and decrease the $\beta$-sheet content, leading to a more stable enzyme. Thus, a trade-off effect between HBA and HBD, either activation or deactivation, can be observed for a certain DES.

Secondly, DESs can affect the 3-D structure of enzymes in an aqueous environment. The functional configuration of enzymes is essentially related to the folding and unfolding degree. Several factors including hydrophobicity, solvent polarity and hydrogen bond characteristics of ILs can affect separately or together the protein stability and activity (Weingartner et al. 2012). Similarly, the concentration of DESs in an aqueous solution had significant effect on the unfolding and refolding process of the enzyme, which could be determined by spectroscopy technologies such as intrinsic fluorescence and CD spectroscopy (Esquembre et al. 2013). The two methods can effectively estimate the folded degree of proteins compared to the native-like secondary and tertiary structures. A redshift of the fluorescence emission spectra of tryptophan residues in lysozyme was observed when tryptophan side chain was exposed to a polar surrounding of water molecules. In neat $\mathrm{ChCl} / \mathrm{U}$ and $\mathrm{ChCl} / \mathrm{Gly}$ solution, the emission maximum of lysozyme shifted from $335 \mathrm{~nm}$ (observed in buffer) to 332 and $329 \mathrm{~nm}$, respectively (Esquembre et al. 2013). However, higher concentration of DESs can cause the irreversible unfolding of lysozyme at high temperatures. Meanwhile, the protein accumulation in low content of DESs buffer at room temperature was interestingly reversible.

In whole-cell biocatalysis, DESs increased the permeability of cells, lowering resistance to mass transfer resistance, thereby improving the reaction efficiency (Xu et al. 2016). ILs similarly can improve the permeability of cells (Xiao et al. 2012). In other cases, DESs can enhance the affordable substrate concentration for a cell catalyst, thereby improving the catalytic rate and yield of the product (Xu et al. 2016). The worst situation is that DESs possibly react with the cell membrane and induce cell apoptosis, finally leading to cell death.

\section{Conclusion and perspective}

Deep eutectic solvents are easier to prepare with different kinds of biocompatible and naturally occurring constituents. Varying the component and ratio yields DESs 
with different $\mathrm{T}_{f}$, polarity, density and viscosity. Some DESs show toxic profile toward laboratory organisms, which depends on the used components, test conditions and organisms. However, most DESs can be considered as "readily biodegradable" solvents. DESs can work as solvents, co-solvents or extracting solvents in a specific biocatalytic reaction. Remarkably, as solvents, DESs (e.g., Gly-based DESs) can activate and stabilize the enzyme, thus achieving a high reaction efficiency. Multiple hydrolases (lipase, protease and epoxide hydrolase) and other enzymes exhibit great catalytic performance in these solvents, which displays their vast potential to replace ILs and organic solvents in biocatalytic reactions. An in-depth understanding of how DESs activate and stabilize enzymes will promote the application of DESs in biocatalysis to step off laboratory scale.

However, DESs in biocatalysis needs researchers to fulfill their full physical-chemical characterization and the important toxicity data. The plausible relationship between the structure and function of enzymes and DESs will be an interesting field to explore. Additionally, the downstream separation of target product from DESs is also a big challenge. More utilization of environmental-friendly and economical solvents in biocatalysis will embody the greenness and sustainability of green chemistry.

\begin{abstract}
Abbreviations
ChCl: choline chloride; MTPB: methyltriphenylphosphonium bromide; DAC: $\mathrm{N}, \mathrm{N}$-diethyl ethanol ammonium chloride; Gly: glycerol; EG: ethylene glycol: DEG: diethylene glycol; TEG: triethylene glycol; U: urea; A: acetamide; OA: oxalic acid; MA: malonic acid; PTSA: para-toluene sulfonic acid; Glc: glucose; Lac: lactose; Raf: raffinose; Fru: fructose; Suc: sucrose; ZnN: zinc nitrate hexahydrate; Choline and geranate: choline bicarbonate/geranic acid; PC3: human prostate cancer cell line; A375: human malignant melanoma cell line; HepG2: human liver hepatocellular cell line; HT29: human colon adenocarcinoma cell line: MCF-7: human breast cancer cell line; OKF6: human oral keratinocyte cell line; H413: carcinoma-derived human oral keratinocyte cells; HelaS3: human cervical cancer cell line; CaOV3: human ovarian cancer cell line; B16F10: mouse skin cancer cel line; AGS: human gastric cancer cell line; WRL-68: human hepatocyte cell line; CALA Candida antarctica lipase A iCALB: Candida antarctica lipase B immobilized on acrylic resin; CALB: Candida antarctica lipase B; CRL: Candida rugosa lipase; PCL: Pseudomonas cepacia lipase; PPL: Porcine pancreas lipase; Alcalase-CLEA: protease from Bacillus licheniformis; Lipase AS: lipase from Aspergillus niger; StEH1: potato epoxide hydrolase; EHAD1: epoxide hydrolase from Agrobacterium radiobacter AD1; BMIM[Tf 2 N]: 1-butyl3-methylimidazolium bis(trifluoromethanesulfonyl) imide; [BMPyr][NTf2]: 1-butyl-1-methylpyrrolidinium Bis(trifluoromethanesulfonyl)imide; [Bmim] HSO4: 1-butyl-3-methylimidazolium hydrosulfate.
\end{abstract}

\section{Authors' contributions}

PX and WYL drafted the manuscript. GWZ, MHZ and NL modified the manuscript. All authors read and approved the final manuscript.

\footnotetext{
Author details

${ }^{1}$ Laboratory of Applied Biocatalysis, School of Food Sciences and Engineering, South China University of Technology, Guangzhou 510640, China. ${ }^{2}$ State Key Laboratory of Pulp and Paper Engineering, South China University of Technology, Guangzhou 510640, China. ${ }^{3}$ State Key Laboratory of Bioreactor Engineering, East China University of Science and Technology, Shanghai 200237, China.
}

\section{Acknowledgements}

We wish to thank the National Natural Science Foundation of China

(21676104; 21336002; 21376096), the Open Funding Project of the State Key Laboratory of Bioreactor Engineering, and the Program of State Key Laboratory of Pulp and Paper Engineering (2017ZD05) for partially funding this work. We also thank Professor Romas Kazlauskas for editing this manuscript.

\section{Competing interests}

The authors declare that they have no competing interests.

\section{Publisher's Note}

Springer Nature remains neutral with regard to jurisdictional claims in published maps and institutional affiliations.

Received: 12 March 2017 Accepted: 16 July 2017

Published online: 21 July 2017

\section{References}

(1992D) OECD 301D Guidelines for testing of chemicals closed bottle test. Organisation of economic cooperation and development, Paris

Abbott AP, Capper G, Davies DL, Munro HL, Rasheed RK, Tambyrajah V (2001) Preparation of novel, moisture-stable, Lewis-acidic ionic liquids containing quaternary ammonium salts with functional side chains. Chem Commun 19:2010-2011

Abbott AP, Harris RC, Ryder KS, D'Agostino C, Gladden LF, Mantle MD (2011) Glycerol eutectics as sustainable solvent systems. Green Chem 13(1):82-90

Anastas P, Eghbali N (2010) Green chemistry: principles and practice. Chem Soc Rev 39(1):301-312

Anastas PT, Warner JC (1998) Principles of green chemistry. green chemistry: theory and practice, Oxford University Press, New York

Atilhan M, Aparicio S (2016) Deep eutectic solvents on the surface of face centered cubic metals. J Phys Chem C 120(19):10400-10409

Attri P, Venkatesu P, Kumar A, Byrne N (2011) A protic ionic liquid attenuates the deleterious actions of urea on al pha-chymotrypsin. Phys Chem Chem Phys 13(38):17023-17026

Blahušiak M, Schlosser Š, Marták J (2013) Extraction of butyric acid with a solvent containing ammonium ionic liquid. Sep Purif Technol 119:102-111

Bommarius AS, Paye MF (2013) Stabilizing biocatalysts. Chem Soc Rev 42(15):6534-6565

Cao SL, Xu H, Li XH, Lou WY, Zong MH (2015) Papain@magnetic nanocrystalline cellulose nanobiocatalyst: a highly efficient biocatalyst for dipeptide biosynthesis in deep eutectic solvents. ACS Sustain Chem Eng 3(7):1589-1599

Cao SL, Deng X, Xu P, Huang ZX, Zhou J, Li X, Zong M, Lou W (2017) Highly efficient enzymatic acylation of dihydromyricetin by the immobilized lipase with deep eutectic solvents as co-solvent. J Agric Food Chem 65(10):2084-2088

Carriazo D, Serrano MC, Gutierrez MC, Ferrer ML, del Monte F (2012) Deepeutectic solvents playing multiple roles in the synthesis of polymers and related materials. Chem Soc Rev 41 (14):4996-5014

Chen FF, Liu YY, Zheng GW, Xu JH (2015) Asymmetric amination of secondary alcohols by using a redox-neutral two-enzyme cascade. ChemCatChem 7(23):3838-3841

Cheng QB, Zhang LW (2017) Highly efficient enzymatic preparation of daidzein in deep eutectic solvents. Molecules 22(1):186

Choi YH, van Spronsen J, Dai YT, Verberne M, Hollmann F, Arends I, Witkamp GJ, Verpoorte R (2011) Are natural deep eutectic solvents the missing link in understanding cellular metabolism and physiology? Plant Physiol 156(4):1701-1705

Cvjetko Bubalo M, Ćurko N, Tomašević M, Kovačević Ganić K, Radojčić Redovniković I (2016) Green extraction of grape skin phenolics by using deep eutectic solvents. Food Chem 200:159-166

Dai Y, van Spronsen J, Witkamp G-J, Verpoorte R, Choi YH (2013a) Natural deep eutectic solvents as new potential media for green technology. Anal Chim Acta 766:61-68 
Dai YT, Witkamp GJ, Verpoorte R, Choi YH (2013b) Natural deep eutectic solvents as a new extraction media for phenolic metabolites in Carthamus tinctorius L. Anal Chem 85(13):6272-6278

Dai Y, Huan B, Zhang HS, He YC (2017) Effective biotransformation of ethyl 4-chloro-3-oxobutanoate into ethyl (S)-4-chloro-3-hydroxybutanoate by recombinant E-coli CCZU-T15 whole cells in ChCl Gly-water media. Appl Biochem Biotechnol 181(4):1347-1359

Daneshjou S, Khodaverdian S, Dabirmanesh B, Rahimi F, Daneshjoo S, Ghazi F, Khajeh K (2017) Improvement of chondroitinases ABCl stability in natural deep eutectic solvents. J Mol Liq 227:21-25

Dennewald D, Weuster-Botz D (2012) Ionic liquids and whole-cell-catalyzed processes ionic liquids in biotransformations and organocatalysis. Wiley, New York, pp 261-314

Durand E, Lecomte J, Baréa B, Piombo G, Dubreucq E, Villeneuve P (2012) Evaluation of deep eutectic solvents as new media for Candida antarctica B lipase catalyzed reactions. Process Biochem 47(12):2081-2089

Durand E, Lecomte J, Barea B, Dubreucq E, Lortie R, Villeneuve P (2013) Evaluation of deep eutectic solvent-water binary mixtures for lipase-catalyzed lipophilization of phenolic acids. Green Chem 15(8):2275-2282

Durand E, Lecomte J, Barea B, Villeneuve P (2014) Towards a better understanding of how to improve lipase-catalyzed reactions using deep eutectic solvents based on choline chloride. Eur J Lipid Sci Technol 116(1):16-23

Esquembre R, Sanz JM, Wall JG, del Monte F, Mateo CR, Ferrer ML (2013) Thermal unfolding and refolding of lysozyme in deep eutectic solvents and their aqueous dilutions. Phys Chem Chem Phys 15(27):11248-11256

Gangu SA, Weatherley LR, Scurto AM (2009) Whole-cell biocatalysis with ionic liquids. Curr Org Chem 13(13):1242-1258

Garcia G, Aparicio S, Ullah R, Atilhan M (2015) Deep eutectic solvents: physicochemical properties and gas separation applications. Energy Fuels 29(4):2616-2644

Gonzalez-Martinez D, Gotor V, Gotor-Fernandez V (2016) Application of deep eutectic solvents in promiscuous lipase-catalysed aldol reactions. Eur J Org Chem 8:1513-1519

Gorke JT, Srienc F, Kazlauskas RJ (2008) Hydrolase-catalyzed biotransformations in deep eutectic solvents. Chem Commun 10:1235-1237

Guajardo N, Domínguez de María P, Ahumada K, Schrebler RA, Ramírez-Tagle R, Crespo FA, Carlesi C (2017) Water as cosolvent: non viscous deep eutectic solvents for efficient lipase-catalyzed esterifications. ChemCatChem 9(8):1393-1396

Guan Z, Li LY, He YH (2015) Hydrolase-catalyzed asymmetric carbon-carbon bond formation in organic synthesis. RSC Adv 5(22):16801-16814

Hallett JP, Welton T (2011) Room-temperature ionic liquids: solvents for synthesis and catalysis. 2. Chem Rev 111(5):3508-3576

Hammond OS, Bowron DT, Edler KJ (2016) Liquid structure of the choline chloride-urea deep eutectic solvent (reline) from neutron diffraction and atomistic modelling. Green Chem 18(9):2736-2744

Harifi-Mood AR, Ghobadi R, Divsalar A (2017) The effect of deep eutectic solvents on catalytic function and structure of bovine liver catalase. Int J Biol Macromol 95:115-120

Hayyan M, Hashim MA, Al-Saadi MA, Hayyan A, AINashef IM, Mirghani MES (2013a) Assessment of cytotoxicity and toxicity for phosphoniumbased deep eutectic solvents. Chemosphere 93(2):455-459

Hayyan M, Hashim MA, Hayyan A, Al-Saadi MA, AINashef IM, Mirghani MES, Saheed OK (2013b) Are deep eutectic solvents benign or toxic? Chemosphere 90(7):2193-2195

Hayyan M, Looi CY, Hayyan A, Wong WF, Hashim MA (2015) In vitro and in vivo toxicity profiling of ammonium-based deep eutectic solvents. PLoS ONE 10(2):e0117934

Hayyan M, Mbous YP, Looi CY, Wong WF, Hayyan A, Salleh Z, Mohd-Ali O (2016) Natural deep eutectic solvents: cytotoxic profile. Springerplus 5:913

Hummel W, Gröger H (2014) Strategies for regeneration of nicotinamide coenzymes emphasizing self-sufficient closed-loop recycling systems. J Biotechnol 191:22-31

Juneidi I, Hayyan M, Hashim MA (2015) Evaluation of toxicity and biodegradability for cholinium-based deep eutectic solvents. RSC Adv 5(102):83636-83647

Juneidi I, Hayyan M, Ali OM (2016) Toxicity profile of choline chloride-based deep eutectic solvents for fungi and Cyprinus carpio fish. Environ Sci Pollut R 23(8):7648-7659
Juneidi I, Hayyan M, Hashim MA, Hayyan A (2017) Pure and aqueous deep eutectic solvents for a lipase-catalysed hydrolysis reaction. Biochem Eng J 117((Part A)):129-138

Kim SH, Park S, Yu H, Kim JH, Kim HJ, Yang YH, Kim YH, Kim KJ, Kan E, Lee SH (2016) Effect of deep eutectic solvent mixtures on lipase activity and stability. J Mol Catal B-Enzym 128:65-72

Kleiner B, Schörken U (2015) Native lipase dissolved in hydrophilic green solvents: a versatile 2-phase reaction system for high yield ester synthesis. Eur J Lipid Sci Technol 117(2):167-177

Kleiner B, Fleischer P, Schörken U (2016) Biocatalytic synthesis of biodiesel utilizing deep eutectic solvents: a two-step-one-pot approach with free lipases suitable for acidic and used oil processing. Process Biochem 51(11):1808-1816

Krystof M, Perez-Sanchez M, de Maria PD (2013) Lipase-catalyzed (Trans)esterification of 5-hydroxy-methylfurfural and separation from HMF esters using deep-eutectic solvents. Chemsuschem 6(4):630-634

Lindberg D, Revenga MD, Widersten M (2010) Deep eutectic solvents (DESs) are viable cosolvents for enzyme-catalyzed epoxide hydrolysis. J Biotechnol 147(3-4):169-171

Marták J, Schlosser Š (2016) New mechanism and model of butyric acid extraction by phosphonium ionic liquid. J Chem Eng Data 61(9):2979-2996

Maugeri Z, de Maria PD (2014) Whole-cell biocatalysis in deep-eutectic-solvents/aqueous mixtures. Chemcatchem 6(6):1535-1537

Maugeri Z, Domínguez de María P (2014) Benzaldehyde lyase (BAL)-catalyzed enantioselective CC bond formation in deep-eutectic-solvents-buffer mixtures. J Mol Catal B Enzym 107:120-123

Maugeri Z, Leitner W, Domínguez de María P (2013) Chymotrypsin-catalyzed peptide synthesis in deep eutectic solvents. Eur J Org Chem 20:4223-4228

Mbous YP, Hayyan M, Wong WF, Looi CY, Hashim MA (2017) Unraveling the cytotoxicity and metabolic pathways of binary natural deep eutectic solvent systems. Sci Rep 7:41257

Monhemi H, Housaindokht MR, Moosavi-Movahedi AA, Bozorgmehr MR (2014) How a protein can remain stable in a solvent with high content of urea: insights from molecular dynamics simulation of Candida antarctica lipase B in urea: choline chloride deep eutectic solvent. Phys Chem Chem Phys 16(28):14882-14893

Muller CR, Lavandera I, Gotor-Fernandez V, de Maria P (2015) Performance of recombinant-whole-cell-catalyzed reductions in deep-eutecticsolvent-aqueous-media mixtures. Chemcatchem 7(17):2654-2659

$\mathrm{Ni}$ Y, Xu JH (2012) Biocatalytic ketone reduction: a green and efficient access to enantiopure alcohols. Biotechnol Adv 30(6):1279-1288

Paiva A, Craveiro R, Aroso I, Martins M, Reis RL, Duarte ARC (2014) Natural deep eutectic solvents -solvents for the 21 st century. ACS Sustain Chem Eng 2(5):1063-1071

Pant PL, Shankarling GS (2017) Deep eutectic solvent/lipase: two environmentally benign and recyclable media for efficient synthesis of $\mathrm{N}$-aryl amines. Catal Lett 147(6):1371-1378

Papadopoulou AA, Efstathiadou E, Patila M, Polydera AC, Stamatis H (2016) Deep eutectic solvents as media for peroxidation reactions catalyzed by heme-dependent biocatalysts. Ind Eng Chem Res 55(18):5145-5151

Peters C, Rudroff F, Mihovilovic MD, Bornscheuer U (2017) Fusion proteins of an enoate reductase and a Baeyer-Villiger monooxygenase facilitate the synthesis of chiral lactones. Biol Chem 398(1):31-37

Petkovic M, Hartmann DO, Adamova G, Seddon KR, Rebelo LPN, Pereira CS (2012) Unravelling the mechanism of toxicity of alkyltributylphosphonium chlorides in Aspergillus nidulans conidia. New J Chem 36(1):56-63

Pöhnlein M, Ulrich J, Kirschhöfer F, Nusser M, Muhle-Goll C, Kannengiesser B, Brenner-Weiß G, Luy B, Liese A, Syldatk C, Hausmann R (2015) Lipase-catalyzed synthesis of glucose-6-O-hexanoate in deep eutectic solvents. Eur J Lipid Sci Technol 117(2):161-166

Potdar MK, Kelso GF, Schwarz L, Zhang CF, Hearn MTW (2015) Recent developments in chemical synthesis with biocatalysts in ionic liquids. Molecules 20(9):16788-16816

Procentese A, Johnson E, Orr V, Campanile AG, Wood JA, Marzocchella A, Rehmann L (2015) Deep eutectic solvent pretreatment and subsequent saccharification of corncob. Bioresour Technol 192:31-36

Qin YZ, Li YM, Zong MH, Wu H, Li N (2015) Enzyme-catalyzed selective oxidation of 5-hydroxymethylfurfural (HMF) and separation of HMF and 2,5-diformylfuran using deep eutectic solvents. Green Chem 17(7):3718-3722 
Radosevic K, Bubalo MC, Srcek VG, Grgas D, Dragicevic TL, Redovnikovic IR (2015) Evaluation of toxicity and biodegradability of choline chloride based deep eutectic solvents. Ecotoxicol Environ Saf 112:46-53

Ren HW, Chen CM, Wang QH, Zhao DS, Guo SH (2016) The properties of choline chloride-based deep eutectic solvents and their performance in the dissolution of cellulose. BioResources 11(2):5435-5451

Roosen C, Muller P, Greiner L (2008) Ionic liquids in biotechnology: applications and perspectives for biotransformations. Appl Microbiol Biotechnol 81(4):607-614

Savile CK, Janey JM, Mundorff EC, Moore JC, Tam S, Jarvis WR, Colbeck JC, Krebber A, Fleitz FJ, Brands J, Devine PN, Huisman GW, Hughes GJ (2010) Biocatalytic asymmetric synthesis of chiral amines from ketones applied to sitagliptin manufacture. Science 329(5989):305

Shahbaz K, Mjalli FS, Hashim MA, AlNashef IM (2011) Using deep eutectic solvents based on methyl triphenyl phosphonium bromide for the removal of glycerol from palm-oil-based biodiesel. Energy Fuels 25(6):2671-2678

Sheldon RA (2016) Biocatalysis and biomass conversion in alternative reaction media. Chem Eur J 22(37):12983-12998

Siebenhaller S, Muhle-Goll C, Luy B, Kirschhöfer F, Brenner-Weiss G, Hiller E, Günther M, Rupp S, Zibek S, Syldatk C (2017) Sustainable enzymatic synthesis of glycolipids in a deep eutectic solvent system. J Mol Catal B Enzym. doi:10.1016/j.molcatb.2017.01.015

Smith EL, Abbott AP, Ryder KS (2014) Deep eutectic solvents (DESs) and their applications. Chem Rev 114(21):11060-11082

Stepankova V, Vanacek P, Damborsky J, Chaloupkova R (2014) Comparison of catalysis by haloalkane dehalogenases in aqueous solutions of deep eutectic and organic solvents. Green Chem 16(5):2754-2761

Thuy Pham TP, Cho C-W, Yun Y-S (2010) Environmental fate and toxicity of ionic liquids: a review. Water Res 44(2):352-372

Tian XM, Zhang SQ, Zheng LY (2016) Enzyme-catalyzed henry reaction in choline chloride-based deep eutectic solvents. J Microbiol Biotechnol 26(1):80-88

Tufvesson P, Lima-Ramos J, Nordblad M, Woodley JM (2011) Guidelines and cost analysis for catalyst production in biocatalytic processes. Org Process Res Dev 15(1):266-274

van Osch D, Zubeir LF, van den Bruinhorst A, Rocha MAA, Kroon MC (2015) Hydrophobic deep eutectic solvents as water-immiscible extractants. Green Chem 17(9):4518-4521

van Rantwijk F, Sheldon RA (2007) Biocatalysis in ionic liquids. Chem Rev 107(6):2757-2785

Vitale P, Abbinante VM, Perna FM, Salomone A, Cardellicchio C, Capriati V (2016) Unveiling the hidden performance of whole cells in the asymmetric bioreduction of aryl-containing ketones in aqueous deep eutectic solvents. Adv Synth Catal 358:1-10

Wachtmeister J, Rother D (2016) Recent advances in whole cell biocatalysis techniques bridging from investigative to industrial scale. Curr Opin Biotechnol 42:169-177

Wang Q, Yao X, Tang S, Lu X, Zhang X, Zhang S (2012) Urea as an efficient and reusable catalyst for the glycolysis of poly(ethylene terephthalate) wastes and the role of hydrogen bond in this process. Green Chem 14(9):2559-2566

Weingartner H, Cabrele C, Herrmann C (2012) How ionic liquids can help to stabilize native proteins. Phys Chem Chem Phys 14(2):415-426

Weiz G, Braun L, Lopez R, de María PD, Breccia JD (2016) Enzymatic deglycosylation of flavonoids in deep eutectic solvents-aqueous mixtures: paving the way for sustainable flavonoid chemistry. J Mol Catal B Enzym 130:70-73

Wen Q, Chen JX, Tang YL, Wang J, Yang Z (2015) Assessing the toxicity and biodegradability of deep eutectic solvents. Chemosphere 132:63-69

Wu BP, Wen Q, Xu H, Yang Z (2014) Insights into the impact of deep eutectic solvents on horseradish peroxidase: activity, stability and structure. $J$ Mol Catal B Enzym 101:101-107

Wu X, Li G, Yang H, Zhou H (2015) Study on extraction and separation of butyric acid from clostridium tyrobutyricum fermentation broth in PEG/ $\mathrm{Na}_{2} \mathrm{SO}_{4}$ aqueous two-phase system. Fluid Phase Equilib 403:36-42

Xiao ZJ, Du PX, Lou WY, Wu H, Zong MH (2012) Using water-miscible ionic liquids to improve the biocatalytic anti-Prelog asymmetric reduction of prochiral ketones with whole cells of Acetobacter sp. CCTCC M209061. Chem Eng Sci 84:695-705
Xu P, Xu Y, Li XF, Zhao BY, Zong MH, Lou WY (2015) Enhancing asymmetric reduction of 3-chloropropiophenone with immobilized Acetobacter sp. CCTCC M209061 cells by using deep eutectic solvents as cosolvents. ACS Sustain Chem Eng 3(4):718-724

Xu P, Zheng GW, Du PX, Zong MH, Lou WY (2016) Whole-cell biocatalytic processes with ionic liquids. ACS Sustain Chem Eng 4(2):371-386

Yang SL, Duan ZQ (2016) Insight into enzymatic synthesis of phosphatidylserine in deep eutectic solvents. Catal Commun 82:16-19

Yang TX, Zhao LQ, Wang J, Song GL, Liu HM, Cheng H, Yang Z (2017) Improving whole-cell biocatalysis by addition of deep eutectic solvents and natural deep eutectic solvents. ACS Sustain Chem Eng 5(7):5713-5722

Zakrewsky M, Banerjee A, Apte S, Kern TL, Jones MR, Del Sesto RE, Koppisch AT, Fox DT, Mitragotri S (2016) Choline and geranate deep eutectic solvent as a broad-spectrum antiseptic agent for preventive and therapeutic applications. Adv Healthc Mater 5(11):1282-1289

Zhang Q, De Oliveira Vigier K, Royer S, Jerome F (2012) Deep eutectic solvents: syntheses, properties and applications. Chem Soc Rev 41(21):7108-7146

Zhang CW, Xia SQ, Ma PS (2016) Facile pretreatment of lignocellulosic biomass using deep eutectic solvents. Bioresour Technol 219:1-5

Zhao DB, Liao YC, Zhang ZD (2007) Toxicity of ionic liquids. Clean Soil Air Water 35(1):42-48

Zhao H, Baker GA, Holmes S (2011a) New eutectic ionic liquids for lipase activation and enzymatic preparation of biodiesel. Org Biomol Chem 9(6):1908-1916

Zhao H, Baker GA, Holmes S (2011b) Protease activation in glycerol-based deep eutectic solvents. J Mol Catal B Enzym 72(3-4):163-167

Zhao H, Zhang C, Crittle TD (2013) Choline-based deep eutectic solvents for enzymatic preparation of biodiesel from soybean oil. J Mol Catal B Enzym 85-86:243-247

Zhao BY, Xu P, Yang FX, Wu H, Zong MH, Lou WY (2015) Biocompatible deep eutectic solvents based on choline chloride: characterization and Application to the extraction of rutin from Sophora japonica. ACS Sustain Chem Eng 3(11):2746-2755

Zhao KH, Cai YZ, Lin XS, Xiong J, Halling P, Yang Z (2016) Enzymatic synthesis of glucose-based fatty acid esters in bisolvent systems containing ionic liquids or deep eutectic solvents. Molecules 21(10):1294

Zhou P, Wang X, Zeng C, Wang W, Yang B, Hollmann F, Wang Y (2017a) Deep eutectic solvents enable more robust chemoenzymatic epoxidation reactions. ChemCatChem 9(6):934-936

Zhou PF, Wang XP, Yang B, Hollmann F, Wang YH (2017b) Chemoenzymatic epoxidation of alkenes with Candida antarctica lipase B and hydrogen peroxide in deep eutectic solvents. RSC Adv 7(21):12518-12523

\section{Submit your manuscript to a SpringerOpen ${ }^{\circ}$ journal and benefit from:}

- Convenient online submission

- Rigorous peer review

- Open access: articles freely available online

- High visibility within the field

- Retaining the copyright to your article

Submit your next manuscript at $\boldsymbol{\nabla}$ springeropen.com 